\title{
Work-Family Conflict, Marital Satisfaction and Marital Stability among Malaysian Chinese Dual-Earner Couples
}

Leong Mei San \& Rumaya Juhari

To Link this Article: http://dx.doi.org/10.6007/IJARBSS/v11-i12/11796

DOI:10.6007/IJARBSS/v11-i12/11796

Received: 06 October 2021, Revised: 09 November 2021, Accepted: 25 November 2021

Published Online: 13 December 2021

In-Text Citation: (San \& Juhari, 2021)

To Cite this Article: San, L. M., \& Juhari, R. (2021). Work-Family Conflict, Marital Satisfaction and Marital Stability among Malaysian Chinese Dual-Earner Couples. International Journal of Academic Research in Business and Social Sciences, 11(12), 527-540.

\section{Copyright: (c) 2021 The Author(s)}

Published by Human Resource Management Academic Research Society (www.hrmars.com)

This article is published under the Creative Commons Attribution (CC BY 4.0) license. Anyone may reproduce, distribute, translate and create derivative works of this article (for both commercial and non0-commercial purposes), subject to full attribution to the original publication and authors. The full terms of this license may be seen at: http://creativecommons.org/licences/by/4.0/legalcode

\section{Vol. 11, No. 12, 2021, Pg. $527-540$}

Full Terms \& Conditions of access and use can be found at http://hrmars.com/index.php/pages/detail/publication-ethics 


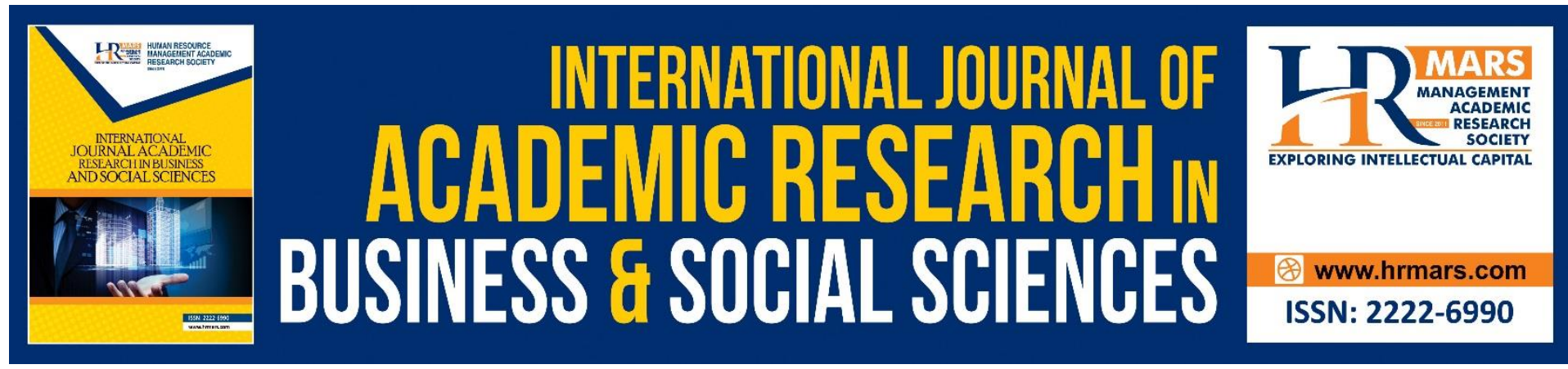

\title{
Work-Family Conflict, Marital Satisfaction and Marital Stability among Malaysian Chinese Dual- Earner Couples
}

\author{
Leong Mei San \& Rumaya Juhari \\ Department of Human Development and Family Studies, Faculty of Human Ecology, \\ University Putra Malaysia, 43400 Serdang, Selangor \\ Email: rumaya@upm.edu.my
}

\begin{abstract}
There has been a steady increase in the rate of involvement of women in the labour workforce in Malaysia. The traditional male-breadwinner-female-homemaker model which is consistent with the Confucian value is being challenged as more families are shifting toward a dualearner model. When both husband-and-wife work to contribute financially for the family, they are required to balance up between work and family. Malaysian Chinese is the largest minority group in Malaysia and experienced the highest prevalence of work-family conflict. Therefore, this study aimed to examine the relationships between work-family conflict (workto-family and family-to-work conflict) with marital satisfaction and marital stability. A total of 134 couples $(n=268)$ participated in this study. Results revealed significant correlations between work-family conflict with marital satisfaction and marital stability except for wife's work-to-family conflict and marital stability. The findings showed that marriages among dualearner couples experiencing high levels of work-family conflict are at a higher risk of marital dissolution and a lower level of marital satisfaction. Further discussions and implications of the findings are reported in the article.
\end{abstract}

Keywords: Work-Family Conflict, Marital Satisfaction, Marital Stability, Dual-Earner couples, Malaysian Chinese

\section{Introduction}

Most individuals marry at some point in their lives and wish their marriages to be long-lasting and satisfying (Karney \& Bradbury, 2020; Wong et al., 2014). However, the divorce rates are rising in Western countries (Hirschman, 2016). Similar trend is found by the increased divorce cases in Malaysia (Sam \& Ghani, 2014). The crude divorce rate in Malaysia has increased from 1.6 (2018) to 1.8 (2019) per thousand population (Department of Statistic Malaysia, 2020). Marriage seems to be fragile in today's society. This could be due to less stigma is attached to divorce nowadays (Wong et al., 2014).

Why marriages do not last long? There were inadequate empirical studies explaining the causes of divorces (Mo, 2016). However, Mo (2016) proposed the main reasons of divorce are (1) increased in women's social status, (2) industrialization and modernization, and (3) divorce is more tolerated and accepted culturally. The increased of women's social status is partially 
contributed by the involvement of women in labour force. Meanwhile, Sam and Ghani (2014) declared that the determinants of divorce among Malaysians were due to marriage at a later age and absence of children. In Malaysia, participation of women in the labour force has been on consistent rise, subsequently causing an increase of dual-earner families (Ma, 2017). It was reported that the female labour force participation rate had risen from 55.3 percent in the second quarter of 2018 to 55.8 percent in the second quarter of 2019 (Department of Statistic Malaysia, 2019). It is fair to speculate that the emerging trend of increasing dual-earner families is likely to continue with women's involvement in the workforce.

It is also speculated that there will be a gradual increase of marital related issues that may or may not lead to divorce cases in Malaysia as life is getting more stressful. Both husband and wife have to find sense of balance between work and family domains. A study investigated the main triggers of divorce in Asian concluded that social and economic background differences between couples in China, and domestic violence in Indonesia were the main reasons of divorce (Subarimaniam et al., 2017). In China, improved living standards and social productivity have changed people's perception towards divorce. Divorce is seen as a solution to the problems faced in a marriage. Future studies are suggested to identify the enduring factors that lead toward marital dissatisfaction and eventually lead toward marital dissolution involving Asian countries (Subarimaniam et al., 2017).

When more couples are expected to experience both work and family roles simultaneously, it is intriguing to find out if juggling between these two roles will have an impact on marital stability. Therefore, work-family conflict has received remarkable attention from researchers in recent years. It was proposed that the increase in income for women raises their bargaining power in marriage (Wang et al., 2020). This poses a challenge to the traditional malebreadwinner-female-homemaker model because women are able to sustain themselves financially after divorce. Money is not the only reason for women to remain married anymore. Instead, married individuals may decide to stay in marriage depending on their satisfaction level with their marriages while coping with work and family stress.

Marital stability is worth researching because early problem detection and intervention in marriage were found to be helpful in improving marital satisfaction as divorce brings about a lot of negative consequences to both the couples and their children (Demir-Dagdas et al., 2018; Hashemi \& Homayuni, 2017). Furthermore, the Malaysia National Population and Family Development Board (2014) reported that 30\% of first marriages among Malaysians ended up in divorce within the first five years of marriage. Such figure further strengthened the purpose of investigating factors that contribute to marital satisfaction since it is predictive of marital stability (Margelisch et al., 2017) Typically, marriages do not end in divorce before going through a process. Individual's marital satisfaction level contributes towards their marital stability. This is because marital satisfaction is considered a necessary and the most proximal reason predicting marital stability (Margelisch et al., 2017) Marital satisfaction is found positively correlated (significant) to marital stability for both husband and wife (Ross et al., 2019).

Divorce has high social impact as individual and societal costs are involved (Demir-Dagdas et al., 2018; Hashemi \& Homayuni, 2017). Children experience emotional, security, and academic insecurities, and divorcees experience work productivity and issues in maintaining 
family relationship. At the society level, divorce contributes to higher crime rate, substance abuse, as well as emotional and mental health risk (i.e., suicide attempts) which increases the financial cost of maintaining the public health (Demir-Dagdas et al., 2018). All these indicate that marital satisfaction and positive marriage experiences are an important area to both the social sciences and the medical field. Therefore, this study aimed to investigate such possibility from the perspective of marital satisfaction and work-family conflict.

\section{Research Objectives}

1. To examine the relationships between work-family conflict (work-to-family and family-to-work conflict) and marital satisfaction.

2. To examine the relationships between work-family conflict (work-to-family and family-to-work conflict) and marital stability.

3. To examine the relationships between marital satisfaction and marital stability.

\section{Literature Review}

There are different domains in our daily life. Work and family are said to be the two most important aspects of one's life (Zainal et al., 2020) and serve as the most appropriate classification of life domains for working parents with children (Jayasingam et al., 2021). Individual's positive and negative experiences at work spill over to marital behaviours at home through psychological availability (Shockley et al., 2017). Furthermore, individuals experiencing work-to-family conflict tend to interact more negatively with their spouses and children (Lavner \& Clark, 2017). These studies showed that experiences at work are closely related to the family domain.

The concept of work-family conflict originated from the Role Theory where role conflict was defined as "a form of inter role conflict, in which the demands of work and family roles are incompatible in some respect so that participation in one role is more difficult because of participation in the other role" (Greenhaus \& Beutell, 1985, p.77). Work and family domains were primarily investigated in past studies utilising Western samples from developed countries (Ratnesh et al., 2019). Intrinsically, literature in the field of work-family conflict is dominated by the Western perspective (Liu \& Cheung, 2015). More cross-cultural studies involving different races are needed in work-family conflict research (Molina, 2021). Understanding work-life domains from a cultural perspective is needed (Perrigino et al., 2018).

When one aspect of life (work/family role) is taking up more time, humans have limited resources left for the other aspects of life (work/family role). Most importantly, work and family lives are interdependent (Greenhaus \& Beutell, 1985). There are two directions of work-family conflict, which are work-to-family (WTF) and family-to-work (FTW) conflict. Work-to-family conflict happens when work role interferes with family role. On the other hand, family-to-work conflict happens when family role interferes with work role (Shockley et al., 2017). For example, when one has to work overtime and cannot attend to the housework or child care responsibilities, work-to-family conflict happens. Family-to-work conflict happens when one has less time and commitment towards their work due to family responsibilities.

The involvement of women in the labour force continues to rise which creates issues such as changes in gender roles, marital conflict, partnership, and family financial decisions (Wang et 
al., 2020). It was proposed that one of the reasons contributing to family instability following increased female employment is that the roles of women and men in marriage have not changed in a symmetrical way (Oláh et al., 2017). On top of that, it was mentioned that work role has to be understood within a larger societal context as it is interrelated with other life roles (Jayasingam et al., 2021). Work role cannot be fully understood as a standalone construct but with gender roles, cultural background, contextual perceptions, and values (Perrigino et al., 2018). These lend support to research on dual-career families among Malaysians as part of the effort to understand the issues raised and how the participation of women in the labour force has impacted family life, particularly marital satisfaction. A metaanalysis reported a significant negative correlation between work-family conflict and couple relationship quality (Fellows et al., 2016). The prevalence of marital dissatisfaction was reported at $37.3 \%$ in a study involving married Malaysians (Ahmad Faizal et al., 2017). Malaysian school teachers also reported poor psychological well-being when experienced high level of work-family conflict (Panatik et al., 2011). In addition, high work-family conflict also affected Malaysian working women's sleep quality (Aazami et al., 2016). Higher level of work-family conflict is also related to lower level of job satisfaction among Malaysian employees (Zainal et al., 2020) and Malaysian academicians (Rahman et al., 2020).

Furthermore, the studies investigating work-family conflict in the Malaysian setting mentioned above did not examine the impact of work-family conflict on marital satisfaction. The crux of the matter is the limited number of studies that had looked into marital satisfaction in Malaysia (Abidin et al., 2018; Mustafa et al., 2013; Ng et al., 2009). The lack of studies in this area thus limits the understanding of both work-family conflict and marital satisfaction. This signifies the importance of research in this field of study in order to add on and expand the knowledge on marital satisfaction. Furthermore, Malaysian Chinese have the highest prevalence in experiencing work-family conflict as compared to Indians and Malays. This is because they are working in formal sectors (i.e., professional, technical, clerical, and sales workers) and are more likely to spend less time with their families (Mahpul \& Abdullah, 2011). Therefore, this study aims to investigate how work-family conflict is experienced among Malaysian Chinese and the impact of work-family conflict on the level of marital satisfaction.

In an earlier study investigating work-family conflict among married working female employees, high work-family conflict is negatively associated with mental health (Zhou et al., 2018). Another study also found high level of work-family conflict among female working professionals (Khursheed et al., 2019). . On the other hand, administrative employees in a semi-government company in Malaysia reported low level of work-family conflict and job stress (Jamadin et al., 2015). Thus far, these studies involved participants from different ethnicity where the Malays were the main respondents of the surveys and the participants were mainly government or semi-government employees. Therefore, this study aims to investigate the level of work-family conflict experienced among different working-class of Malaysian Chinese. This is an effort to address the inconsistencies found on the level of workfamily conflict reported in past research.

\section{Research Hypotheses}

1. Work-to-family conflict is negatively correlated with marital satisfaction for both husband and wife. 
2. Family-to-work conflict is negatively correlated with marital satisfaction for both husband and wife.

3. Work-to-family conflict is negatively correlated with marital stability for both husband and wife.

4. Family-to-work conflict is negatively correlated with marital stability for both husband and wife.

5. Marital satisfaction is positively correlated with marital stability for husband and wife.

\section{Methodology}

\section{Design and Sample}

This is a quantitative, cross-sectional, and correlational survey study that investigated the relationships between work-family conflict with marital satisfaction and marital stability among Malaysian Chinese dual-earner couples. Data were collected from 134 Malaysian Chinese dual-earner couples $(n=268)$ residing in Kuala Lumpur and Klang Valley, Malaysia. The sample in this study aged between 27 to 63 years. The mean age for husbands was 46.33 $(S D=7.90)$ and the mean age for wives was $43.53(S D=7.10)$. The mean years of marriage was 14.20 years. More than half of the participants hold diploma and above qualifications, $58.82 \%$ for husbands and $68.33 \%$ for wives. The majority of the sample had at least one child $(90.70 \%)$. Husbands in this sample are mostly working as professionals $(24.17 \%)$ and in the services and sales industry (23.33\%). On the other hand, wives in this sample are mostly working as clerical support staff (39.17\%) and professionals (30.00\%). Wives ( $M=$ RM5185.23) earn less than husbands ( $M=\mathrm{RM} 7016.86)$ on average. Slightly more than two-thirds of the wives are earning less than RM5000.00 per month (75.23\%). On the other hand, $53.98 \%$ of husbands earn more than RM5000.00 per month.

\section{Procedures}

Participants fulfilled the inclusion criteria were recruited via purposive sampling and snowballing technique. The inclusion criteria are, (1) both husband and wife are Malaysian Chinese residing in Kuala Lumpur or Klang Valley, Malaysia, (2) both husband and wife are working full-time currently, (3) this is the first marriage, (4) the couple is currently staying in the same house, and (5) both spouses agreed to take part in this study. Couples were provided with two sets of consent forms and questionnaires. This is a paper and pencil survey. Couples were told to complete the survey independently without discussing with their partners. No monetary remuneration was offered to the couples.

\section{Instrument}

\section{Work-Family Conflict}

Work-family conflict was measured with the 10-item Work-family and Family-work Conflict Scales (Netemeyer et al., 1996). The two subscales measuring work-to-family and family-towork conflicts contain 5-item in each subscale. Participants were asked to consider how the demands and time from work affected their family life and vice-versa. A 7-point Likert scale (where 1 = strongly disagree and $7=$ strongly agree) was used to indicated how much the participants agreed or disagreed with statements such as, "My job produces strain that makes it difficult to fulfil family duties" for the work-to-family conflict subscale and "My home life interferes with my responsibilities at work such as getting to work on time, accomplishing daily tasks, and working overtime" for the family-to-work conflict subscale. Scores from all 
the items in the subscale are totalled to form a final score. This scale has been found highly reliable in past research. This scale also showed high reliability in the current study for both husband and wife ( $\alpha=.91$ for husband's work-to-family conflict subscale, $\alpha=.90$ for husband's family-to-work conflict subscale, $\alpha=.92$ for wife's work-to-family conflict subscale, and $\alpha=.92$ for wife's family-to-work conflict subscale).

\section{Marital Satisfaction}

Marital satisfaction was measured with the six-item Quality Marriage Index (QMI; Norton, 1983). This scale measures a person's global evaluation of their marriage. Participants were required to rate evaluative item such as "I really feel like part of a team with my partner". The first five items were rated on a 7-point Likert scale from 1 (I do not agree at all) to 7 (perfect). The last item is a 10-point Likert scale, required participants to rate their degree of happiness in their marriage from 1 (very unhappy) to 10 (totally perfect). Scores from all the items are totalled to form a final score. A high score indicates a high level of marital satisfaction and happiness while a low score represents a low level of marital satisfaction and a low sense of happiness in the marriage. This scale has been found to be highly reliable for husbands $(\alpha=$ .93 ) and wives ( $\alpha=.96$; Dennison et al., 2014) in past research. This scale showed highly reliability in the current study ( $\alpha=.97$ for husbands and $\alpha=.97$ for wives).

\section{Marital Stability}

Marital stability was measured with the 19-item Marital Instability Index (MII; Booth et al., 1983). This scale measures a person's evaluation of their marriage stability. Participants were required to rate evaluative item such as "I thought my marriage is in trouble". The items were rated on a 4-point Likert scale from 0 (never) to 3 (now). The scores were reversed coded before it was analysed. Scores from all the items are totalled to form a final score. A higher score in this scale indicates a higher level of marital stability. This scale has been found to be highly reliable ( $\alpha=.75$ ) (Booth et al., 1983) and the reliability score in this study was .89 for husbands and .93 for wives.

\section{Analysis}

Pearson-correlation analysis was conducted using the SPSS (version 20) to examine the correlations between work-family conflict (work-to-family and family-to-work conflict), marital satisfaction, and marital stability. Descriptive statistics (mean, $M$ and standard deviation, $S D$ ) are reported in Table 1. Correlation between studied variables are reported in Table 2.

\section{Results}

Table 1 summarizes the mean (M) and standard deviation (SD) of husbands and wives' responses on the variable assessed in this study. Both husbands and wives in the sample reported similar mean scores for work-to-family and family-to-work conflict. Husbands reported higher mean scores for marital satisfaction and marital stability as compared to wives on average. 
Table 1: Descriptive Statistics

\begin{tabular}{lcccc}
\hline \multirow{2}{*}{ Variable } & \multicolumn{2}{c}{ M } & \multicolumn{2}{c}{ SD } \\
\cline { 2 - 5 } & Husband & Wife & Husband & Wife \\
\hline Work-to-family conflict & 17.40 & 17.52 & 7.48 & 7.40 \\
Family-to-work conflict & 13.91 & 13.91 & 5.93 & 6.02 \\
Marital satisfaction & 34.03 & 32.55 & 7.24 & 6.77 \\
Marital stability & 53.76 & 52.87 & 4.82 & 6.74 \\
\hline
\end{tabular}

The hypotheses were examined using Pearson's correlation (one-tailed) test. Table 2 showed the Pearson-correlation between work-to-family conflict, family-to-work conflict, marital satisfaction, and marital stability. Results showed that there is a significant negative correlation between work-to-family conflict and marital satisfaction for both husband $(r=-$ $.265, p=.001)$ and wife $(r=-.205, p=.009)$. Hypothesis 1 is supported. Similarly, a significant negative correlation between family-to-work conflict and marital satisfaction is found for both husband $(r=-.212, p=.007)$ and wife $(r=-.284, p=.000)$. Hypothesis 2 is supported.

Table 2: Correlation Matrix between the Studied Variables

\begin{tabular}{lcccc}
\hline Variables & $\mathbf{1}$ & $\mathbf{2}$ & $\mathbf{3}$ & $\mathbf{4}$ \\
\hline 1.Work-to-family conflict & 1 & $.549^{* *}$ & $-.205^{* *}$ & -.052 \\
& & $p=.000$ & $p=.009$ & $p=.277$ \\
2.Family-to-work conflict & $.607^{* *}$ & 1 & $-.284^{* *}$ & $-.279^{* *}$ \\
& $p=.000$ & & $p=.000$ & $p=.001$ \\
3.Marital satisfaction & $-.265^{* *}$ & $-.212^{* *}$ & 1 & $.468^{* *}$ \\
& $p=.001$ & $p=.007$ & & $p=.000$ \\
4.Marital stability & $-.173^{*}$ & $-.145^{*}$ & $.474^{* *}$ & 1 \\
& $p=.023$ & $p=.048$ & $p=.000$ & \\
\hline
\end{tabular}

${ }^{*} p<.05 ;{ }^{*} p<.001$

Values above the diagonal are for wife. Values below the diagonal are for husband

Hypothesis 3 is partially supported. There is a significant negative correlation between workto-family conflict and marital stability for husband $(r=-.173, p=.023)$. On the other hand, no significant correlation is found between work-to-family conflict and marital stability for wife $(r=-.052, p=.277)$. Hypothesis 4 is supported for both husband $(r=-.145, p=.048)$ and wife $(r=-.279, p=.001)$. Family-to-work conflict is significantly negatively correlated with marital stability. Last but not least, hypothesis 5 is supported for both husband $(r=.474, p=.000)$ and wife $(r=.468, p=.000)$. There is a strong, and significant positive correlation between marital satisfaction and marital stability for both husband and wife.

The findings suggest that higher level of work-family conflict (work-to-family and family-towork conflict) interferes with marital satisfaction and marital stability. Couples are less satisfied with their marriage when they are faced with high levels of work-family conflict. Furthermore, work-family conflict (work-to-family and family-to-work conflict) also interferes with husband's marital stability. As for wife, their marital stability is affected by family-towork conflict but not work-to-family conflict. Overall, hypothesis 3 is partially supported (supported for husband but not for wife), hypotheses 1, 2, 4, and 5 were supported. 


\section{Discussion}

The negative association between work-family conflict (work-to-family and family-to-work conflict) and marital satisfaction and marital stability do not come as surprise in light of previous research. Previous research has consistently reported a negative association between work-to-family/family-to-work conflict and marital satisfaction (Fellows et al., 2016; Liu \& Cheung, 2015; Minnotte et al., 2015). This finding is also consistent with Levy's (2015) research findings high work involvement is negatively correlated with marital satisfaction. This finding is in accordance with the inter-role conflict proposed (Greenhaus \& Beutell, 1985) where individuals have limited time and energy to fulfil the needs from work and family domains. When the work-family conflict is high, a person is struggling with high demands from the work and family domains, and they then experience a lower level of marital satisfaction and stability. This discontentment over unfulfilled roles and demands have a negative impact on the level of marital satisfaction and stability. Conversely, when the demands from the work and family domains are low, couples are more satisfied with their marriage, the marriage is more stable as well.

Furthermore, this finding is consistent with a past study conducted in Malaysia among school teachers where the psychological well-being of teachers is negatively correlated with workfamily conflict (Panatik et al., 2011). The Malaysian Chinese dual-earner couples in this study showed similar experiences where marital satisfaction is significantly negatively correlated with work-to-family and family-to-work conflict supporting the meta-analysis (Fellows et al., 2016). Similar to other employees in Malaysia (Zainal et al., 2020) and Malaysian academicians (Rahman et al., 2020), dual-earner couples in this study also experienced high level of work-family conflict that affected their marital satisfaction. Furthermore, work-tofamily conflict is found to have a negative impact not only on personal psychological wellbeing but with their marital experiences as well. The impact of work-to-family conflict is significant and requires immediate attention especially when marital satisfaction is closely linked to psychological health (Margelisch et al., 2017). Culturally, it appears that Malaysian Chinese dual-earner couples are reporting similar experiences where work-family conflict has a negative impact on marital satisfaction and stability. The findings also revealed that work and family domains are the two most important domains among Malaysian Chinese dualearner couples. In addition, work-family conflict (work-to-family and family-to-work conflict) is negatively correlated to marital stability. Couples associated their marital stability with the work-family conflict faced. This is consistent with past study suggesting marital stability is affected by what a person experience within and outside of the marriage (Hilpert et al., 2015). In relation to the findings of Malaysia Chinese working as professionals, sales, and clerical work experiencing the highest prevalence in work-family conflict (Mahpul \& Abdullah, 2011), this is supported by the findings from this study. Looking at the occupations of the sample, almost $50 \%$ of the husbands are working as professionals and services and sales. As for wives, slightly more than $69 \%$ of them are working as professionals and clerical and support staff. The significant negative correlations between work-family conflict and marital satisfaction and marital stability showed how stress from work and family are impacting couples' marital satisfaction and the stability of their marriages.

Consistent with past studies, marital satisfaction played an important role in marital stability with a moderate correlation (Margelisch et al., 2017). This finding corroborated past studies which suggested declining marital satisfaction as the antecedent of divorce (Subarimaniam et 
al., 2017). Furthermore, marital satisfaction is significantly correlated with marital stability (He et al., 2018). In a longitudinal study by $\mathrm{He}$ et al. (2018), marital satisfaction was consistently positively correlated to marital stability for both husbands and wives. The findings revealed that marriage does not end in divorce automatically. Consistent with past studies and suggestions, marital satisfaction is a proximal factor predicting marital satisfaction (Margelisch et al., 2017).

Given the rising number of divorce in Malaysia, the findings in this study is particularly useful for government to develop and design more family-friendly policies as an effort to improve marital satisfaction and stability among Malaysian workforce. This is because divorce has detrimental effects on both adult and children. In addition, there are costs of divorce to pay at both the individual and society level (Demir-Dagdas et al., 2018). For example, children of emotionally divorced parents experienced higher level of emotional distress and aggressive behaviours (Hashemi \& Homayuni, 2017). Having structural support from workplace such as flexible work schedules and childcare support extended to the private sector (Jayasingam et al., 2021) and encouragement of using such services without experiencing backlash from the organization (Perrigino et al., 2018) might be able to help dual-earner couples to cope better with work-family conflict. Malaysia government has introduced flexible work arrangements such as staggered working hours in the public sector since 2007 but it was not extended to the private sector (Che Shaari \& Amirul, 2020). For example, the working hours of fathers with childcare responsibilities can be reduce to 30-32 hours per week as recommended in German for mothers to maintain their time spent in employment (Oláh et al., 2017).

\section{Conclusion}

Work and family are the two most important domains in our lives. Unfortunately, dual-earner couples have to struggle between these two important domains of life due to the changing society and family structure. Adjustments between couples are important in mitigating the negative impact of work-family conflict on marital satisfaction and marital stability. Fulfilling demands from multiple roles (i.e. spouse, parent, child, and employee) requires effort, time, energy, and effective strategies. Learning how to cope and balancing between the demanding life roles is an important skill to develop among married individuals. Marital support was found mediating the relationships between work-family conflict and marital satisfaction and stability (Ross et al., 2019).

In conclusion, this study revealed that work-family conflict is (work-to-family and family-towork conflict) significantly correlated with marital satisfaction and marital stability. Companies and government need to look into making the workplace more conducive for their employees. Likewise, married individuals must also learn to balance up the demands between these two critical domains in life. This is because marital conflict which can lead to marital instability and divorce can have adverse impact on everyone involved. Parental divorce had a negative impact on children's cognitive, emotional, psychological, and social development (Anderson, 2014). Future studies may investigate the role of work life balance and work family enrichment with marital satisfaction and marital stability. The potential factors such as coping skills in mitigating the negative impact of work-family conflict on marital satisfaction and stability can be explore in future studies. This will provide further insight on how work and family domains can mutually benefit each other in addition to the negative associations 
between work-family conflict with marital satisfaction and marital stability. Also, insights on the coping strategies used to manage work-family conflict can be investigated.

\section{References}

Aazami, S., Mozafari, M., Shamsuddin, K., \& Akmal, S. (2016). Work-family conflict and sleep disturbance: The Malaysian working women study. Industrial Health, 54(1), 50-57. https://doi.org/10.2486/indhealth.2015-0086

Abidin, R. Z., Ismail, K., Hassan, S. S. S., \& Sudan, S. A. (2018). Marital satisfaction, communication and coping strategy among Malaysian married couples: Factors prediction and model testing. International Journal of Engineering \& Technology, 7(3.21), 408-414. https://www.sciencepubco.com/index.php/ijet/article/view/17202

Faizal, A. S., Sidi, H., Wahab, S., Drph, L. S., Zin, N. M., \& Baharuddin, N. (2017). Assessment of marital dissatisfaction and its association with sexual dysfunction and psychiatric morbidities among primary health attenders in Malaysia. International Medical Journal Malaysia, 16(2), 19-26. https://doi.org/10.31436/imjm.v16i2.320

Anderson, J. (2014). The impact of family structure on the health of children: Effects of divorce. Linacre Quarterly, 81(4), 378-387. https://doi.org/10.1179/0024363914Z.00000000087

Booth, A., Johnson, D., \& Edwards, J. N. (1983). Measuring marital instability. Journal of Marriage and Family, 45(2), 387-394.

https://doi.org/https://doi.org/10.2307/351516

Che Shaari, S., \& Amirul, S. R. (2020). Regulating flexible working arrangements (FWAS) in Malaysian private sector: Are we there yet? International Journal of Business, Economics, and Law, 21(4), 13-22.

Demir-Dagdas, T., Isik-Ercan, Z., Intepe-Tingir, S., \& Cava-Tadik, Y. (2018). Parental divorce and children from diverse backgrounds: Multidisciplinary perspectives on mental health, parent-child relationships, and educational experiences. Journal of Divorce and Remarriage, 59(6), 469-485. https://doi.org/10.1080/10502556.2017.1403821

Dennison, R. P., Koerner, S. S., \& Segrin, C. (2014). A dyadic examination of family-of-origin influence on newlyweds' marital satisfaction. Journal of Family Psychology, 28(3), 429-435. https://doi.org/10.1037/a0036807

Department of Statistic Malaysia. (2019). Principal statistics of labour force, Malaysia, second quarter (Q2) 2019.

https://www.dosm.gov.my/v1/index.php?r=column/cthemeByCat\&cat=149\&bul_id= ekx5ZDVkVFAyWGg3WHNLUnJWL3RwUT09\&menu_id=U3VPMIdoYUxzVzFaYmNkW XZteGduZz09

Department of Statistics, Malaysia. (2020). Marriage and divorce statistic, Malaysia, 2020. Retrieved from https://www.dosm.gov.my/v1/index.php?r=column/cthemeByCat\&cat=453\&bul_id= QmZ1cE4xRFAvYWQ0R05hTk1rWm5KQT09\&menu_id=LOpheU43NWJWRWVSZkIWdz Q4TIhUUTO9

Fellows, K. J., Chiu, H. Y., Hill, E. J., \& Hawkins, A. J. (2016). Work-family conflict and couple relationship quality: A meta-analytic study. Journal of Family and Economic Issues, 37(4), 509-518. https://doi.org/10.1007/s10834-015-9450-7

Greenhaus, J. H., \& Beutell, N. J. (1985). Sources of conflict between work and family roles. The Academy of Management Review, 10(1), 76-88.

https://doi.org/https://doi.org/10.2307/258214 
Hashemi, L., \& Homayuni, H. (2017). Emotional divorce: Child's well-being. Journal of Divorce and Remarriage, 58(8), 631-644. https://doi.org/10.1080/10502556.2016.1160483

He, Q., Zhong, M., Tong, W., Lan, J., Li, X., Ju, X., \& Fang, X. (2018). Forgiveness, marital quality, and marital stability in the early years of Chinese marriage: An actor-partner interdependence mediation model. Frontiers in Psychology, 9(SEP), 1-11. https://doi.org/10.3389/fpsyg.2018.01520

Hilpert, P., Kuhn, R., Anderegg, V., \& Bodenmann, G. (2015). Comparing simultaneously the effects of extra-dyadic and intra-dyadic experiences on relationship outcomes. Family Science, 6(1), 129-142. https://doi.org/10.1080/19424620.2015.1082018

Hirschman, C. (2016). Gender, the status of women, and family structure in Malaysia. Malaysian Journal of Economic Studies, 53(1), 33-50. https://faculty.washington.edu/charles/new PUBS/A127.pdf

Jamadin, N., Mohamad, S., Syarkawi, Z., \& Noordin, F. (2015). Work - Family Conflict and Stress: Evidence from Malaysia. Journal of Economics, Business and Management, 3(2), 309-312. https://doi.org/10.7763/joebm.2015.v3.200

Jayasingam, S., Lee, S. T., \& Mohd Zain, K. N. (2021). Demystifying the life domain in work-life balance: A Malaysian perspective. Current Psychology. https://doi.org/10.1007/s12144-021-01403-5

Karney, B. R., \& Bradbury, T. N. (2020). Research on marital satisfaction and stability in the 2010s: Challenging conventional wisdom. Journal of Marriage and Family, 82(1), 100116. https://doi.org/10.1111/jomf.12635

Khursheed, A., Mustafa, F., Arshad, I., \& Gill, S. (2019). Work-Family Conflict among Married Female Professionals in Pakistan. Management Studies and Economic Systems (MSES), $4(2), 123-130$.

Lavner, J. A., \& Clark, M. A. (2017). Workload and marital satisfaction over time: Testing lagged spillover and crossover effects during the newlywed years. Journal of Vocational Behaviour, 101, 67-76. https://doi.org/10.1016/j.jvb.2017.05.002.Workload

Levy, D. V. (2015). Workaholism and marital satisfaction among female professionals. The Family Journal: Conseling and Therapy for Couples and Families, 23(4), 330-335. https://doi.org/10.1177/1066480715601109

Liu, H., \& Cheung, F. M. (2015). Testing crossover effects in an actor-partner interdependence model among Chinese dual-earner couples. International Journal of Psychology, 50(2), 106-114. https://doi.org/10.1002/ijop.12070

Ma, Q. (2017). Female labor force participation in Malaysia: Time-series evidence. South East Asia Journal of Contemporary Business, Economics and Law, 14(3), 1-7.

Mahpul, I. N., \& Abdullah, N. A. (2011). The prevalence of work-family conflict among mothers in peninsular Malaysia. International Journal of Humanities and Social Science, 1(17), 154-161. http://familyrepository.Ippkn.gov.my/178/1/The_Prevalence_of_WorkFamily_Conflict_among_Mothers_in_Peninsular_Malaysia.pdf

Margelisch, K., Schneewind, K. A., Violette, J., \& Perrig-Chiello, P. (2017). Marital stability, satisfaction and well-being in old age: variability and continuity in long-term continuously married older persons. Aging and Mental Health, 21(4), 389-398. https://doi.org/10.1080/13607863.2015.1102197

Minnotte, K. L., Minnotte, M. C., \& Bonstrom, J. (2015). Work-family conflicts and marital satisfaction among US workers: Does stress amplification matter? Journal of Family and Economic Issues, 36(1), 21-33. https://doi.org/10.1007/s10834-014-9420-5

Mo, L. I. (2016). A review of the determinants of divorce: A cross-national perspective. 
International Journal of Sociology of the Family, 42(1-2), 29-47. https://www.jstor.org/stable/44504669

Molina, J. A. (2021). The work-family conflict: Evidence from the recent decade and lines of future research. Journal of Family and Economic Issues, 42(s1), 4-10. https://doi.org/10.1007/s10834-020-09700-0

Mustafa, H., Hasim, M. J., Aripin, N., \& Abdul Hamid, H. (2013). Couple types, ethnicity and marital satisfaction in Malaysia. Applied Research in Quality of Life, 8(3), 299-317. https://doi.org/10.1007/s11482-012-9200-z

National Population and Family Development Board, N. (2016). Fifth Malaysian population and family survey [MPFS-5]. http://familyrepository.lppkn.gov.my/659/1/Report on Key Findings Fifth Malaysian Populationand Family Survey \%28MPFS-5\%29 2014.pdf

Netemeyer, R. G., Boles, J. S., \& McMurrian, R. (1996). Development and validation of workfamily conflict and family-work conflict scales. Journal of Applied Psychology, 81(4), 400-410. https://doi.org/10.1037/0021-9010.81.4.400

Ng, K., Loy, J. T. C., Gudmunson, C. G., \& Cheong, W. (2009). Gender differences in marital and life satisfaction among Chinese Malaysians. Sex Roles, 60(1-2), 33-43. https://doi.org/10.1007/s11199-008-9503-6

Norton, R. (1983). Measuring marital quality: A critical look at the dependent variable. Journal of Marriage and Family, 45(1), 141. https://doi.org/10.2307/351302

Oláh, L. S., Richter, R., \& Kotowska, I. E. (2017). The new roles of men and women and implications for families and societies: Summary report of key findings for WP3. Families and Societes, 71, 1-51.

Panatik, S. A. B., Badri, S. K. Z., Rajab, A., Abdul, H. R., \& Shaha, I. M. (2011). The impact of work family conflict on psychological well-being among school teachers in Malaysia. Procedia - Social and Behavioral Sciences, 29, 1500-1507. https://doi.org/10.1016/j.sbspro.2011.11.390

Perrigino, M. B., Dunford, B. B., \& Wilson, K. S. (2018). Work-family backlash: The "dark side" of work-life balance (WLB) policies. Academy of Management Annals, 12(2), 600-630. https://doi.org/10.5465/annals.2016.0077

Rahman, M., Ali, N. A., Jantan, A. H., Mansor, Z., \& Rahaman, S. (2020). Work to family, family to work conflicts and work family balance as predictors of job satisfaction of Malaysian academic community. Journal of Enterprising Communities, People and Places in the Global Economy. https://doi.org/10.1108/JEC-05-2020-0098

Ratnesh, M., Ali, A., \& Sinha, A. R. (2019). Determinants of work-life balance: A cross-cultural review of selected Asian countries. Space and Culture, India, 7(1), 223-239. https://doi.org/10.20896/saci.v7i1.478

Ross, D. B., Gale, J., Wickrama, K. K. A. S., Goetz, J., \& Vowels, M. (2019). The impact of family economic strain on work-family conflict, marital support, marital quality, and marital stability during the middle years. Journal of Personal Finance, 18(2), 9-24.

Sam, S. F. M., \& Ghani, P. A. (2014). Determinants of divorce among women in Malaysia. 1-9. http://familyrepository.Ippkn.gov.my/381/2/Extended_Abstract__DETERMINANTS_OF_DIVORCE_AMONG_WOMEN_IN_MALAYSIA.pdf

Shockley, K. M., Shen, W., DeNunzio, M. M., Arvan, M. L., \& Knudsen, E. A. (2017). Disentangling the relationship between gender and work-family conflict: An integration of theoretical perspectives using meta-analytic methods. Journal of Applied Psychology, 102(12), 1601-1635. https://doi.org/10.1037/apl0000246

Subarimaniam, N., Hassan, S. A., \& Zakaria, N. S. (2017). The driving forces of marital 
dissolution in Asian countries :A systematic review of literatures. The Family Journal: Conseling and Therapy for Couples and Families, 25(2), 123-129. https://doi.org/10.1177/1066480717697301

Wang, Z., Lou, Y., \& Zhou, Y. (2020). Bargaining power or specialization? Determinants of household decision making in Chinese rural migrant families. SAGE Open, 10(4), 1-15. https://doi.org/10.1177/2158244020980446

Wong, L. C., Chu, A. M. Y., \& Chan, C. L. W. (2014). Measuring the transgression-related interpersonal motivations inventory in marital relationships: Forgiveness in the Chinese context (C-TRIM). Research on Social Work Practice, 24(3), 356-363. https://doi.org/10.1177/1049731513498622

Zainal, N., Zawawi, D., Aziz, Y. A., \& Ali, M. H. (2020). Work-family conflict and job performance: Moderating effect of social support among employees in malaysian service sector. International Journal of Business and Society, 21(1), 79-95.

Zhou, S., Da, S., Guo, H., \& Zhang, X. (2018). Work-family conflict and mental health among female employees: A sequential mediation model via negative affect and perceived stress. Frontiers in Psychology, 9(APR), 1-10. https://doi.org/10.3389/fpsyg.2018.00544 